\title{
Retraction
}

\section{Retracted: Phytoliths as Emerging Taxonomic Tools for Identification of Plants: An Overview}

\author{
Journal of Botany \\ Received 25 November 2014; Accepted 25 November 2014; Published 10 December 2014 \\ Copyright (C) 2014 Journal of Botany. This is an open access article distributed under the Creative Commons Attribution License, \\ which permits unrestricted use, distribution, and reproduction in any medium, provided the original work is properly cited.
}

The paper titled "Phytoliths as Emerging Taxonomic Tools for Identification of Plants: An Overview" [1], published in Journal of Botany, has been retracted at the request of the author as it was submitted without the consent of the author's graduate supervisor.

\section{References}

[1] S. Abdul Shakoor and M. A. Bhat, "Phytoliths as emerging taxonomic tools for identification of plants: an overview," Journal of Botany, vol. 2014, Article ID 318163, 9 pages, 2014. 